\title{
The Influence of Organic Manure and Biochar on Cashew Seedling Performance, Soil Properties and Status
}

\author{
Beatrice Abanum Nduka1, Moses Ogunwole Ogunlade ${ }^{2}$, Dele Omoyele Adeniyi ${ }^{3}$, \\ Isaac Kayode Oyewusi ${ }^{4}$, Osasogie Ugioro' ${ }^{1}$, Idrisu Mohammed ${ }^{1}$ \\ ${ }^{1}$ Agronomy Section, Cocoa Research Institute of Nigeria, Ibadan, Nigeria \\ ${ }^{2}$ Soil and Plant Nutrition Section, Cocoa Research Institute of Nigeria, Ibadan, Nigeria \\ ${ }^{3}$ Plant Pathology Section, Cocoa Research Institute of Nigeria, Ibadan, Nigeria \\ ${ }^{4}$ Department of Agricultural Technology, The Federal Polytechnic Ado-Ekiti, Ado-Ekiti, Nigeria \\ Email: beatricenduka@yahoo.com
}

How to cite this paper: Nduka, B.A., Ogunlade, M.O., Adeniyi, D.O., Oyewusi, I.K., Ugioro, O. and Mohammed, I. (2019) The Influence of Organic Manure and Biochar on Cashew Seedling Performance, Soil Properties and Status. Agricultural Sciences, 10, 110-120.

https://doi.org/10.4236/as.2019.101009

Received: November 14, 2018

Accepted: January 19, 2019

Published: January 22, 2019

Copyright $\odot 2019$ by author(s) and Scientific Research Publishing Inc. This work is licensed under the Creative Commons Attribution-NonCommercial International License (CC BY-NC 4.0). http://creativecommons.org/licenses/by-nc/4.0/

\begin{abstract}
A nursery experiment was conducted at Cocoa Research Institute of Nigeria to evaluate the impact of manure on cashew seedlings. Treatments consisted of biochar, compost, combination of biochar + compost and a control. Treatments were applied at rate of $0 \mathrm{~g}$ (control), $5 \mathrm{~g}$ compost, $5 \mathrm{~g}$ biochar and $2.5 \mathrm{~g}$ each of biochar and compost combination into $5 \mathrm{~kg}$ soil in pots, laid out in a completely randomized design (CRD) with three replications. The experiment was monitored for four months in the greenhouse. Data were collected on number of leaves, plant height, stem girth, soil nutrient composition and nutrient uptake, all analyzed using analysis of variance. The treated soils were also assayed on Potato Dextrose Agar for associated mycoflora. The study showed that the soil $\mathrm{P}^{\mathrm{H}}, \mathrm{N}, \mathrm{P}, \mathrm{K}, \mathrm{Ca}$ and $\mathrm{Mg}$ were equally enhanced significantly relative to the control, while Aspergillus, Trichoderma, Beauverie, Penicillium, Lasiodiplodia and Rhizopus cultured treated soils shows that Trichoderma harzianum and Beauverie bassiana were significantly higher in combination of biochar and compost treated soil and posed that their bio-control potential is coupled with soil fertility enhancement characteristics. The results also indicate that stem girth and number of leaves were significantly $(\mathrm{P} \leq 0.05)$ different with respect to applied treatment at the first month after treatments application. The leaf area was not enhances with the application of biochar. Combination of biochar + compost significantly enhanced number of leaves and stem girth at the $4^{\text {th }}$ and $12^{\text {th }}$ weeks after planting. Similarly leaf K and P uptake were significantly $(<0.05)$ increased by the application of organic compost and biochar irrespective of whether combined or not compared to the control seedlings. The effect of biochar and compost
\end{abstract}


on cashew leaf $\mathrm{Ca}$ and $\mathrm{Mg}$ uptake were not significantly different from the control but had a higher value relative to the control. It could therefore be recommended that addition of compost and biochar for sustainable production of cashew seedlings in the nursery be embraced by prospective cashew farmers and seedlings distribution in Nigeria.

\section{Keywords}

Biochar, Cashew, Compost, Nutrient, Mycoflora, Uptake

\section{Introduction}

Biochar research is gaining global interest with a promising potential for development of sustainable agriculture in Africa. Biochar is made by pyrolysis, a thermo-chemical decomposition of biomass at temperatures less than $700^{\circ} \mathrm{C}$ in the presence of little or no oxygen. Lehmann and Joseph [1] widely documented the benefits of biochar to include: mitigation of climate change, energy production, soil improvement and waste management. According to Novak et al. [2], biochar from Switchgrass showed high aliphatic- $C$ character which is expected to contain substrates that may be minerialized by soil microbial activity to improve soil chemical and physical properties. Biochar has elaborate pore structure and large surface area properties [3], with an ability to curtain fertilizer demand [4], and reduce greenhouse gas emissions by about $800 \mathrm{~kg}$ of $\mathrm{CO}_{2}$ per ton of dry feedstock [5]. Within the soil, biochar acts as soil conditioner by improving its physical and biological properties, enhances water holding capacity and soil nutrients retention, and positively alters soil nutrient content and quality [6] [7] [8] [9]. Its effect on plant growth and yield is well documented [10]-[19]. So the recent awareness on need for reduction of residues in food products has necessitated research interest in eco-friendly plant enhancement and management systems. The use of biological control agents among which entomopathogens was studied had achieved a good height in crop protection strategies. However the association of Trichoderma harzianum and Beauverie bassiana with biochar and compost soils indicates a potential bio-control alternative of these amendments in addition to their use in soil fertility enhancement.

Work on cashew nursery soil amendment has been reported [20]; likewise a number of research has been done on biochar as a soil amendment [1] [21] [22]. However, the use of biochar as alternative cashew nursery soil amendment in Nigeria is rare and the knowledge of it in enhancing growth and development of potted cashew seedlings has not been well exploited. Several farm wastes (grain husk, nutshell, wood, crop residues etc.) have carbon [23] and ash [24]. The need to convert these farm residues into a plant management enhancement necessitated this study. Hence, the objective of the study was to evaluate organic fertilizer sources of biochar (made from Cocoa Pod Husk) and compost on cashew seedlings performance and its effect on the chemical and microbial status composition of the soil. 


\section{Material and Methods}

The nursery experiment was carried out at Cocoa Research Institute of Nigeria (CRIN) Ibadan, Oyo state (Lat. $0.7^{\circ} 1$ 'N and Long. $03^{\circ} 52^{\prime} \mathrm{E}$ ). The biochar used was made from dried Cocoa Pod Husk with zero or no oxygen, while the compost was source from the market (A composition of plant and animal waste). Pure cultures of fungal used in this study were obtained and determination of specie affiliation was done according to Rifai, MA. [25], Glare and Inwood [26]. Chemical analysis of the soil, biochar and the compost nutrient was done and the physico-chemical determined using standard procedures. The soil was top dressed with different $0 \mathrm{~g}$ (control), $5 \mathrm{~g}$-compost, $5 \mathrm{~g}$-biochar and $2.5 \mathrm{~g}$ biochar and compost combination per plant. Medium size cashew nuts were planted into each treatments. The experiment was laid out in completely randomized design $(\mathrm{CRD})(4 \times 4 \times 3)$ with three replications. The plot size was four seedlings per treatment. The seedlings were monitored for four months. Manual weeding was done as at when due.

Data collected on vegetative growth parameter were: plant height, stem girth, numbers of leaves/plant and leaf area; interval of collection was four weeks for four months. At the termination of the experiment soil samples were collected for chemical analyzed for physico-chemical properties and were also assayed in-vitro on Potato Dextrose Agar (PDA) at $10^{-5}$ dilution factor, incubated at $29^{\circ} \mathrm{C}+2^{\circ} \mathrm{C}$ and colony growths recorded. Plant leaves samples were also analyzed for mineral content and nutrient uptake and calculated on the cashew leaves samples. Analysis of variance (ANOVA) was carried out on the data for the variables measured during the study period to test for differences between the treatments using SAS [27]. Treatment means were separated using the least significant difference (LSD) test at $\mathrm{P}=0.05$.

\section{Result and Discussion}

The chemical composition of the soil, shown in Table 1 indicated that the soil used in this study needs improvement soil $\mathrm{N}$ was less than $0.15 \%$, which is the optimum according to Sobulo, and Osiname [28] for plant growth. Also, P, K and $\mathrm{Ca}$ were also low in the soil concentration and below satisfactory level when compared to the cashew soil critical level of P-3.7; K-0.12; Ca 0.8. The values of Total $\mathrm{C}, \mathrm{N}$ and $\mathrm{K}$ were higher in the organic compost than that of the biochar. However, $\mathrm{P}$ value (Table 1 ) was high in the biochar content, it is above the critical level needs of the soil.

In Figure 1, the various treatment did not significantly $(\mathrm{P}<0.05)$ affect stem girth and number of leaves, however organic compost and the combination of biochar + compost which shows significant growth enhancement at 4 weeks after planting (WAP) for the two parameters. Onwuka and Nwangwu [29] observed similar trend in the growth parameters of potted Okra. At 12 WAP, sole compost manure and biochar + compost treated soil with cashew seedlings produced significantly higher number of leaves when compared with other 


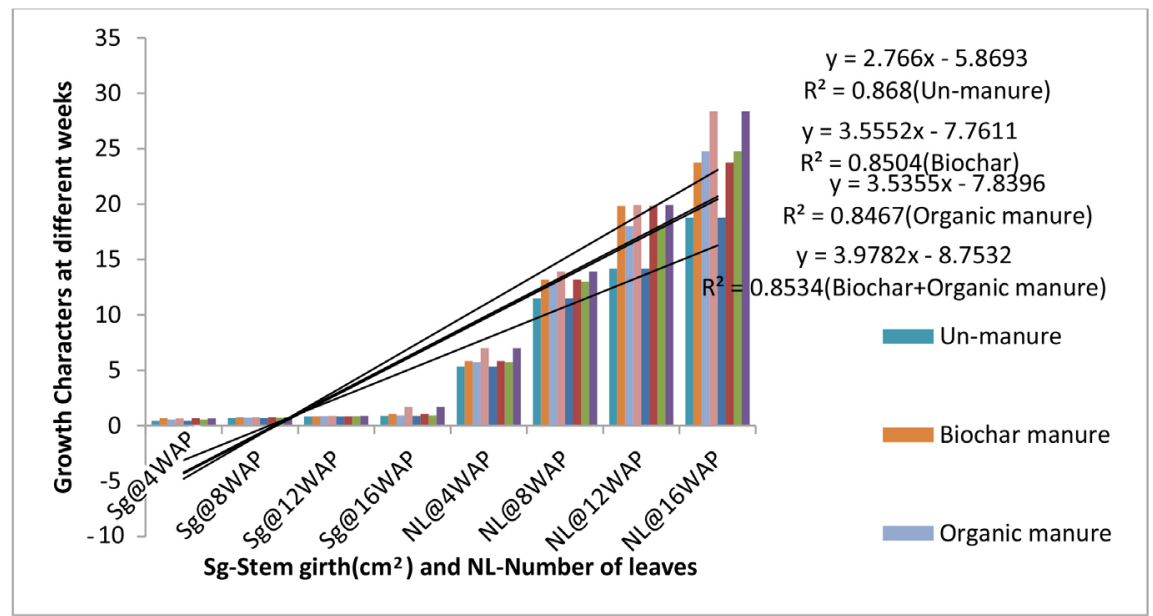

Figure 1. Effect of organic fertilizers on stem girth and number of leaves of cashew seedlings.

Table 1. Pre-cropping chemical properties of soil, biochar and compost used in this study.

\begin{tabular}{ccccccccccc}
\hline Treatments & $\begin{array}{c}\mathrm{P}^{\mathrm{H}} \\
\left(\mathrm{H}_{2} \mathrm{O}\right)\end{array}$ & $\begin{array}{c}\text { Total } \\
\mathrm{C} \%\end{array}$ & $\begin{array}{c}\text { Total } \\
\text { N\% }\end{array}$ & Total P\% & $\begin{array}{c}\text { Exchangeable } \\
\text { basic- } \mathrm{K}^{+}\end{array}$ & $\begin{array}{c}\text { Exchangeable } \\
\text { basic- } \mathrm{Ca}^{2+}\end{array}$ & $\begin{array}{c}\text { Exchangeable } \\
\text { basic- } \mathrm{mg}^{2+}\end{array}$ & $\begin{array}{c}\text { Exchangeable } \\
\text { basic- } \mathrm{Na}^{+}\end{array}$ & $\begin{array}{c}\mathrm{Cu} \\
\mathrm{Zn}\end{array}$ \\
\hline Soil & 5.30 & 0.05 & 0.04 & 0.99 & 0.03 & 0.98 & 1.13 & - & 1.78 & 0.12 \\
Biochar & 9.51 & 8.61 & 0.33 & 7.96 & 0.86 & 3.95 & 2.06 & 0.68 & 4.68 & 1.23 \\
Compost & - & 9.35 & 1.2 & 1.08 & 1.78 & 1.98 & 0.07 & - & - & - \\
\hline
\end{tabular}

treatments. The result obtained was in line to work of [30] [31] [32] with the use of combination of biochar and compost.

Figure 2 showed that leaf area was significantly influence in biochar treated cashew seedlings at $8,12 \mathrm{WAP}$, which indicate that the alkaline nature $\left(\mathrm{P}^{\mathrm{H}}-9.15\right)$ of the cocoa pod husk biochar may have provided nutrients which positively affected the leaf area development of the cashew seedlings. The results also showed comparable similarities among the other treatments applied. This could have being attributed to availability of other nutrient element in the compost. Sarah et al. [33] observed related impact of biochar application on soil properties and plant growth of pot grown Lettuce (Lactuca sativa) and Cabbage (Brassica chinensis). Among the treatments, only organic compost and mixture of biochar and compost significantly influenced the number of leaves at 4 WAP. This corroborates the finding of MoyinJesu [34] who reported that Nitrogen is responsible for good vegetative growth; he equally observed the element to have high contributory influence on organic matter build up.

Figure 3 shows that the association of Trichoderma harzianum and Beauverie bassiana were significantly higher in biochar integrated with organic-treated soil compared with other treatment types. But Beauverie bassiana was only present in the combination of biochar and organic. A similar trend was recorded with the presence of Lasiodiplodia theobromae and Rhizopus nigrican in the untreated control. The fungal genus Beauveria, Vuillemin has species that are often 


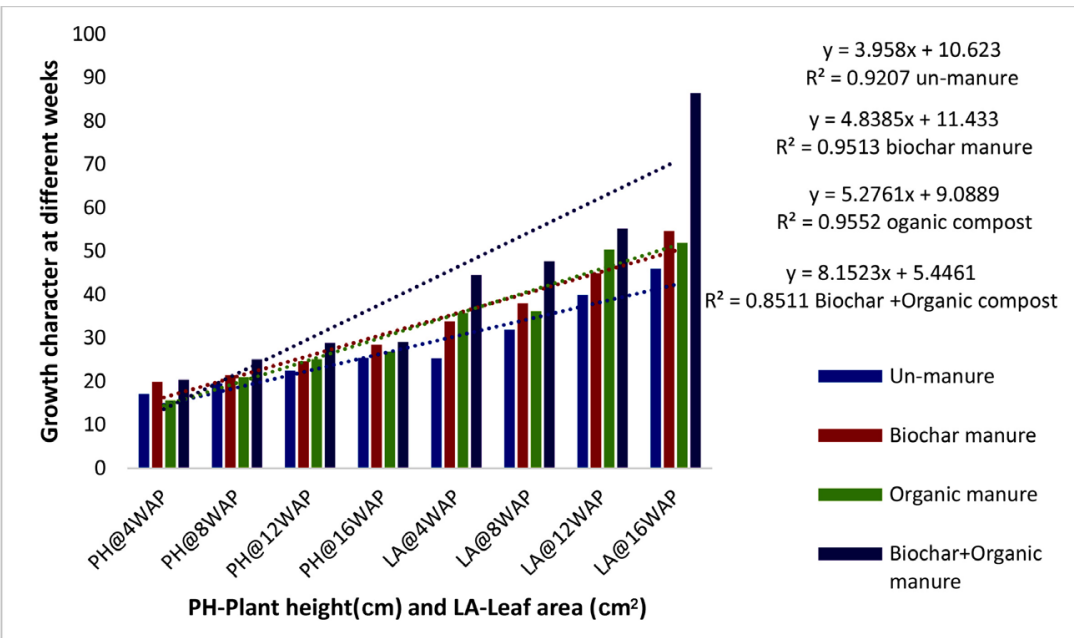

Figure 2. Effect of organic fertilizers on plant height and leaf area of cashew seedlings.

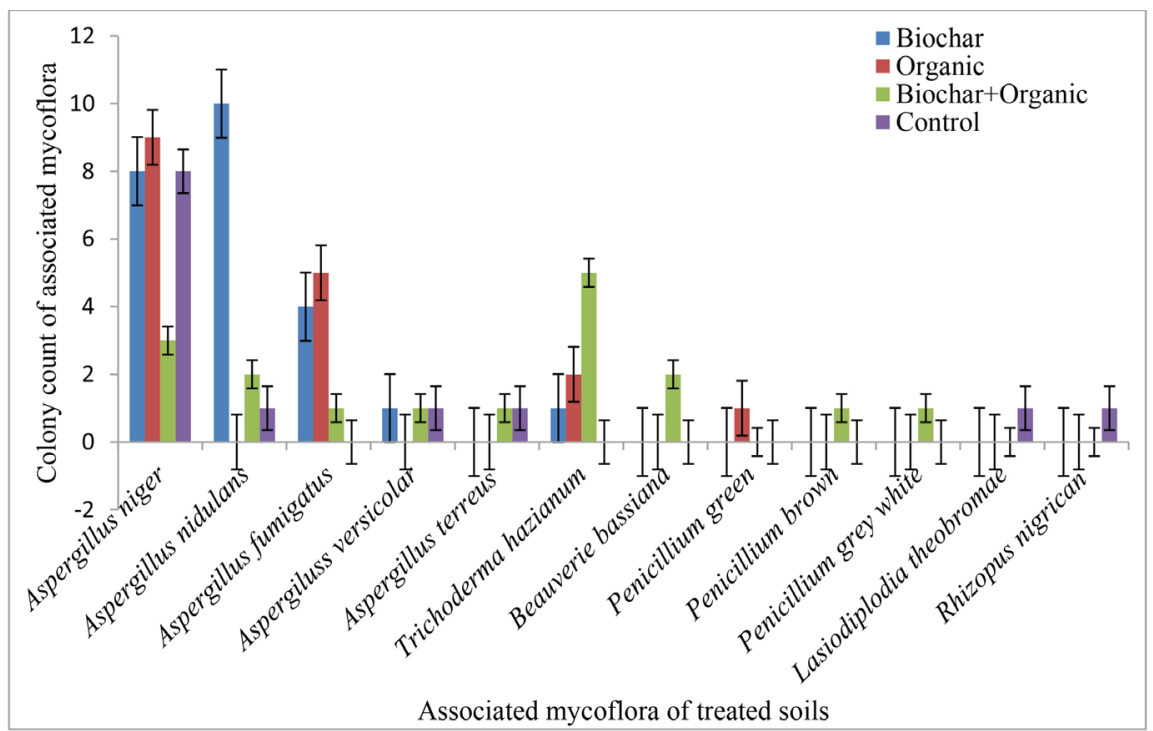

Figure 3. Mycoflora population of Biological applications in soils.

pathogenic to insects, one of most common is $B$. bassiana, an entomopathogen which has extremely broad host range and used as commercial biopesticide for control of insects of agricultural, veterinary and medical significance [35] [36] [37]. The bioactivity of B. bassiana has been proof against many pests in the laboratory and efforts are being made to simulate the results in field condition. Genus Trichoderma are important biocontrol agents of several soil borne phytopathogens [38]. The Trichoderma species serves as a potential alternative to chemical control measure and growing pathogen resistance crop cultivars. The reports of Harman et al., [39] and Renio et al., [40] showed that Trichoderma use different mechanism for control of phytopathogens which includes mycoparasitism which out compete pathogenic fungi for nutrients, secretion for antibiotics and fungal cell wall degrading enzymes.

The soil textural class was sandy loam soil. The soil was slightly acidic with $\mathrm{P}^{\mathrm{H}}$ 
values of $5.30-6.5$ across the soil. More so, the valued obtained in all the treatments varied only slightly with the treatments imposed as shown in Table 2. This was expected because the $\mathrm{P}^{\mathrm{H}}$ of the biochar was 9.51 before its addition to the soil which may have being neutralized indirectly. Similarly Glaser et al. [41] and Randon et al. [42] reported that biochar with high $\mathrm{P}^{\mathrm{H}}$ act as a liming agent thereby increased the soil $\mathrm{P}^{\mathrm{H}}$, while Ilesanmi [43] reported that an increased soil $\mathrm{P}^{\mathrm{H}}$ could be because of the alkaline nature of biochar. The results also shown that the application of biochar significantly influence the Total $\mathrm{C}, \mathrm{N}$, exchangeable $\mathrm{K}$, $\mathrm{Mg}, \mathrm{Cu}$ and $\mathrm{Zn}$, while the organic compost influences soil $\mathrm{P}^{\mathrm{H}}$, Total $\mathrm{C}, \mathrm{N}, \mathrm{P}, \mathrm{Cu}$. The results in Table 2 shown that Biochar + organic compost treatment significantly influence $\mathrm{P}^{\mathrm{H}}$, Total $\mathrm{C}, \mathrm{N}$, exchangeable $\mathrm{Ca}$ and $\mathrm{Na}$ content of the cashew seedlings. This is in line with the work of Scotti et al. [44] in their study of organic amendments as a tool for fertility recovery and Chan et al. [11], Asai et al. [12], Saarnio et al. [18] in their works on effects of fertilizer on plant growth. The use of biochar and compost increased the soil $\mathrm{N}$ thereby meeting the cashew nutrient requirement for $\mathrm{N}$, while that of the combination of biochar + compost influenced the total C concentration and ECE of the soil (Table 2).

Table 3 shows that leaf mineral concentration of the cashew seedlings was significantly different for $\mathrm{Ca}, \mathrm{Na}$ and $\mathrm{Fe}$ in untreated cashew seedlings compare to other treatment. This indicated that some quantities of these nutrients are present in the soil. Compost-treated cashew seedlings had high $\mathrm{Mg}, \mathrm{P}$ and $\mathrm{Cu}$ and the biochar + compost combination treated soil had high $\mathrm{Na}$ and $\mathrm{Mn} \mathrm{nu}-$ trient composition when compare to the other treatment respectively. These finding concurred with earlier works of MoyinJesu [45]. The $\mathrm{K}$ mineral content value (1.37) of the leaves was significantly different from other treatments. Hammond [46] stated in his report that different type of biochar affect the soil, plants in various ways, depending on the climatic condition of the area of study.

The nutrient uptake of the cashew seedling leave shown similarities among the elements measured in the various treatments imposed in this study, apart from $\mathrm{N}, \mathrm{P}$ and $\mathrm{K}$ content. The use of compost manure significantly enhanced $\mathrm{K}$ and $\mathrm{N}$ nutrient uptake when compared to other treatments. The application of compost and a combination of biochar + compost enhances $\mathrm{P}$ uptake compared to other treatments in this study (Table 4). This was corroborated with the findings of Chan et al. [6] and [7]; and that of Van Zwieten et al. [9], who reported that the application of biochar or fertilizer to the soil, increases the rate of nutrient uptake in plants. The use of sole biochar may enhance nutrient uptake but incorporating biochar + compost seemed to give better cashew seedling growth. This is in line with the report of Ofori et al. [47] on the combination of cocoa pod husk and NPK fertilizer.

\section{Conclusion}

This experiment result demonstrated there was increased in chemical concentration of the soil, leaf mineral/nutrient contents and cashew seedling plant development. Therefore taking into consideration that the soil used in this study was 
Table 2. Manuring effect on post-cropping soil chemical and physical properties.

\begin{tabular}{|c|c|c|c|c|c|c|c|c|c|c|c|c|c|c|c|c|c|c|}
\hline Treatments & $\begin{array}{c}\mathrm{P}^{\mathrm{H}} \\
\text { (Water) }\end{array}$ & Sand $\%$ & Silk\% & Clay\% & $\begin{array}{c}\mathrm{Ca} . \\
\mathrm{cmol}\end{array}$ & $\begin{array}{c}\mathrm{Mg} . \\
\mathrm{cmol}\end{array}$ & $\begin{array}{c}\mathrm{Na} . \\
\mathrm{cmol}\end{array}$ & $\begin{array}{c}\mathrm{K} . \\
\mathrm{cmol}\end{array}$ & $\begin{array}{l}\mathrm{AL}^{+\mathrm{H}} \\
\mathrm{cmol}\end{array}$ & $\begin{array}{l}\text { ECE } \\
\mathrm{cmol}\end{array}$ & $\begin{array}{l}\text { Base } \\
\text { Sat.\% } \\
\end{array}$ & $\begin{array}{c}\text { Total } \\
\text { N\% }\end{array}$ & $\begin{array}{c}\text { Total } \\
\mathrm{C} \%\end{array}$ & $\begin{array}{l}\text { AV.P. } \\
\text { mg/kg }\end{array}$ & $\begin{array}{c}\mathrm{Mn} \\
\mathrm{mg} / \mathrm{kg}\end{array}$ & $\begin{array}{c}\mathrm{Fe} . \\
\mathrm{mg} / \mathrm{kg}\end{array}$ & $\begin{array}{c}\mathrm{Cu} \\
\mathrm{mg} / \mathrm{kg}\end{array}$ & $\begin{array}{c}\mathrm{Zn} . \\
\mathrm{mg} / \mathrm{kg}\end{array}$ \\
\hline $\begin{array}{l}\text { Un manure } \\
\text { (Control) }\end{array}$ & $6.37 \mathrm{c}$ & $87.17 \mathrm{~b}$ & $7.20 \mathrm{a}$ & $5.63 \mathrm{~b}$ & $15.96 \mathrm{c}$ & $1.86 \mathrm{~b}$ & $0.82 \mathrm{~b}$ & $0.39 \mathrm{~d}$ & $0.07 a$ & $19.20 \mathrm{c}$ & 99.68 & $0.01 \mathrm{~b}$ & $0.54 \mathrm{~b}$ & $14.78 \mathrm{~b}$ & $88.1 \mathrm{~b}$ & $20.1 \mathrm{ab}$ & $1.5 \mathrm{a}$ & $14.16 \mathrm{a}$ \\
\hline Biochar & $6.55 \mathrm{~b}$ & $85.23 \mathrm{c}$ & $7.17 \mathrm{a}$ & $7.43 a$ & $10.52 \mathrm{~d}$ & $1.98 \mathrm{a}$ & $0.79 \mathrm{c}$ & $0.48 \mathrm{a}$ & $0.07 a$ & $13.82 \mathrm{~d}$ & 99.57 & $0.08 \mathrm{ab}$ & $1.06 \mathrm{ab}$ & $15.95 \mathrm{ab}$ & $96.3 \mathrm{a}$ & $24 a$ & $1.5 \mathrm{a}$ & $13.01 \mathrm{a}$ \\
\hline Compost & $6.58 \mathrm{a}$ & $89.20 \mathrm{a}$ & $6.20 \mathrm{~b}$ & $4.60 \mathrm{c}$ & $16.72 b$ & $1.36 \mathrm{~d}$ & $0.83 \mathrm{~b}$ & $0.42 \mathrm{c}$ & $0.08 \mathrm{a}$ & $19.38 \mathrm{~b}$ & 99.59 & $0.1 \mathrm{a}$ & $1.15 \mathrm{ab}$ & $17.52 \mathrm{a}$ & $73.9 \mathrm{~b}$ & $10.7 \mathrm{c}$ & $1.03 \mathrm{a}$ & $11.01 \mathrm{a}$ \\
\hline $\begin{array}{c}\text { Biochar }+ \\
\text { Compost }\end{array}$ & $6.58 \mathrm{a}$ & $89.20 \mathrm{a}$ & $5.20 \mathrm{c}$ & $5.60 \mathrm{~b}$ & $17.37 \mathrm{a}$ & $1.83 \mathrm{c}$ & $0.89 a$ & $0.45 b$ & $0.07 a$ & $20.76 \mathrm{a}$ & 99.71 & $0.09 \mathrm{a}$ & $1.16 \mathrm{a}$ & $15.76 \mathrm{ab}$ & $67.6 \mathrm{c}$ & $13.05 b$ & $0.96 a$ & $10.18 \mathrm{a}$ \\
\hline
\end{tabular}

Treatment means within each column followed by the same letters are not significantly different at $<\mathrm{P}=0.5$

Table 3. Manuring effect on cashew seedling leaves mineral composition.

\begin{tabular}{|c|c|c|c|c|c|c|c|c|c|c|}
\hline Treatments & $\mathrm{Ca} \%$ & $\mathrm{Mg} \%$ & $\mathrm{Na} \%$ & $\mathrm{~K} \%$ & P\% & $\mathrm{N} \%$ & $\mathrm{Mn} \%$ & $\mathrm{Fe} \%$ & $\mathrm{Cu} \%$ & $\mathrm{Zn} \%$ \\
\hline Unmanure & $3.33 \mathrm{a}$ & $0.38 c$ & $0.36 \mathrm{a}$ & $0.38 \mathrm{~d}$ & $40.82 \mathrm{~d}$ & $1.29 \mathrm{c}$ & $187.24 c$ & $481.23 a$ & $13.44 \mathrm{~d}$ & $61.11 \mathrm{a}$ \\
\hline Compost & $3.14 \mathrm{~b}$ & $0.46 \mathrm{a}$ & $0.28 c$ & $1.28 \mathrm{~b}$ & $92.04 \mathrm{a}$ & $1.87 \mathrm{~b}$ & $191.18 b$ & $191.15 c$ & $19.95 a$ & $48.94 a$ \\
\hline $\begin{array}{c}\text { Biochar }+ \\
\text { Compost }\end{array}$ & $3.03 c$ & $0.43 \mathrm{~b}$ & $0.37 \mathrm{a}$ & $1.15 \mathrm{c}$ & $82.76 b$ & $2.17 \mathrm{a}$ & $212.57 \mathrm{a}$ & $212.57 \mathrm{~b}$ & $18.80 \mathrm{c}$ & $42.51 \mathrm{a}$ \\
\hline
\end{tabular}

Treatment means within each column followed by the same letters are not significantly different at $<\mathrm{P}=0.5$.

Table 4. Manuring effect on nutrient uptake of cashew seedling leaves.

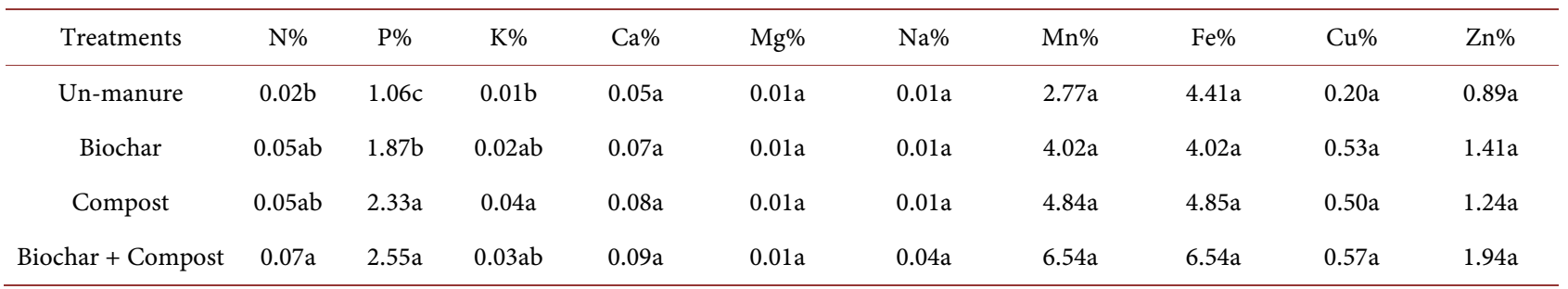

Treatment means within each column followed by the same letters are not significantly different at $<\mathrm{P}=0.5$.

low in its nutrient status, the results obtained from this study shows that the application of biochar, and compost manure solely or in combinations have significant agronomic benefit to the soil. In this research, the impacts of biochar includes: modification of the soil physical and chemical properties, enhancement of cashew seedling vegetative growth parameters and improved nutrient uptake. And the presence of entomopathogen and bio-control agent indicates crop protection advantage of this bio-fertilizer. This study could be furthered with its application on cashew under field conditions to study the impact on soil compaction.

\section{Conflicts of Interest}

The authors declare no conflicts of interest regarding the publication of this paper.

\section{References}

[1] Lehmann, J. and Joseph, S. (2009) Biochar for Environmental Management: Science 
and Technology. Earthscan Publications Ltd., London, 251-270.

[2] Novak, J.M., Busscher, W.J., Watts, D.W., Laird, D.A., Ahmedna, M.A. and Niandou, M.A.S. (2010) Short Term $\mathrm{CO}_{2}$ Mineralization after Additions of Biochar and Switchgrass to a Typic Kandiudult. Geoderma, 154, 281-288.

https://doi.org/10.1016/j.geoderma.2009.10.014

[3] Tenenbaum, D.J. (2009) Bio-Char: Carbon Mitigation from the Ground Up. Environmental Health Perspectives, 117, 70-73. https://doi.org/10.1289/ehp.117-a70

[4] Liu, X.Y., Zhang, A., Ji, C.Y., Joseph, S., Bian, R., Li, L.Q., Pan, G.X. and Paz-Ferreiro, J. (2013) Biochar's Effect on Crop Productivity and the Dependence on Experimental Conditions-A Meta-Analysis of Literature Data. Plant and Soil, 373, 583-594. https://doi.org/10.1007/s11104-013-1806-x

[5] Roberts, K.G., Gloy, B.A., Joseph, S., Scott, N.R. and Lehmann, J. (2009) Life Cycle Assessment of Biochar Systems: Estimating the Energetic, Economic, and Climate Change Potential. Environmental Science and Technology, 44, 827-833. https://doi.org/10.1021/es902266r

[6] Chan, K.Y., Van Zwieten, L., Meszaros I., Downie, A. and Joseph, S. (2008a) Agronomic Values of Greenwaste Biochar as a Soil Amendment. Soil Research, 45, 629-634. https://doi.org/10.1071/SR07109

[7] Chan, K.Y., Van Zwieten, L., Meszaros, I., Downie, A. and Joseph, S. (2008b) Using Poultry Litter Biochars as Soil Amendments. Soil Research, 46, 437-444. https://doi.org/10.1071/SR08036

[8] Steiner, C., de Arruda, M.R., Teixeira, W.G. and Zech, W. (2008) Soil Respiration Curves as Soil Fertility Indicators in Perennial Central Amazonian Plantations Treated with Charcoal, and Mineral or Organic Fertilizers. Tropical Science, 47, 218-230. https://doi.org/10.1002/ts.216

[9] Van Zwieten, L., Kimber, S., Morris, S., Chan, K.Y., Downie, A., Rust, J. and Cowie, A. (2010) Effects of Biochar from Slow Pyrolysis of Papermill Waste on Agronomic Performance and Soil Fertility. Plant and Soil, 327, 235-246. https://doi.org/10.1007/s11104-009-0050-x

[10] Glaser, B., Lehmann, J. and Zech, W. (2002) Ameliorating Physical and Chemical Properties of Highly Weathered Soils in the Tropics with Charcoal-A Review. Biology Fertility Soils, 35, 219-230. https://doi.org/10.1007/s00374-002-0466-4

[11] Chan, K.Y., Van Zwieten, L., Meszaros, I., Downie, A. and Joseph, S. (2007) Agronomic Values of Green Waste Biochar as a Soil Amendment. Austrian Journal of Soil Research, 45, 629-634. https://doi.org/10.1071/SR07109

[12] Asai, H., Samson, B.K., Haefele, S.M., Songyikhangs, K., Homma, K., Kiyono, Y., Inoue Y., Shiraiwa, T. and Horie, T. (2009) Biochar Amendment Techniques for Upland Rice Production in Northern Laos. 1. Soil Physical Properties, Leaf SPAD and Grain Yield. Field Crops Research. 111, 81-84.

https://doi.org/10.1016/j.fcr.2008.10.008

[13] Sohi, S., Lopez-Capel, E., Krull, E. and Bol, R. (2009) Biochar, Climate Change and Soil: A Review to Guide Future Research. CSIRO Land and Water Science Report 05/09, 64 .

[14] Sohi, S.P, Krull, E., Lopez-Capel, E. and Bol, R. (2010) A Review of Biochar and Its Use and Function in Soil. Advance Agronomy, 105, 47-82. https://doi.org/10.1016/S0065-2113(10)05002-9

[15] Waters, D., van Zwieten, L., Singh, B.P., Downie, A., Cowie, A.L. and Lehmann, J. (2011) Biochar in Soil for Climate Change Mitigation and Adaptation. Soil Health 
Climate Change, 29, 345-368. https://doi.org/10.1007/978-3-642-20256-8_15

[16] Barrow, C.J. (2012) Biochar: Potential for Countering Land Degradation and for Improving Agriculture. Applied Geography, 34, 21-28.

https://doi.org/10.1016/j.apgeog.2011.09.008

[17] Spokas, K.A., Cantrell, K.B., Novak, J.M., Archer, D.W., Ippolito, J.A., Collins, H.P. and Lentz, R.D. (2012) Biochar: A Synthesis of Its Agronomic Impact beyond Carbon Sequestration. Journal of Environmental Quality, 41, 973-989. https://doi.org/10.2134/jeq2011.0069

[18] Saarnio, S., Heimonen, K. and Kettunen, R. (2013) Biochar Addition Indirectly Affects $\mathrm{N}_{2} \mathrm{O}$ Emissions via Soil Moisture and Plant $\mathrm{N}$ Uptake. Soil Biology and Biochemistry, 58, 99-106. https://doi.org/10.1016/j.soilbio.2012.10.035

[19] Liu, X., Zhang, A., Ji, C., Joseph, S., Bian, R., Li, L., Pan, G. and Paz-Ferreiro, J. (2013) Biochar's Effect on Crop Productivity and the Dependence on Experimental Conditions-A Meta-Analysis of Literature Data. Plant and Soil, 373, 583-594. https://doi.org/10.1007/s11104-013-1806-x

[20] Nduka, B.A., Adewale, B.D., Akanbi, O.S.O. and Adejobi, K.B. (2015) Nursery Soil Amendments for Cashew Seedling Production: A Comparative Analysis of Coffee Husk and NPK. Journal of Agricultural Science, 7, 111-122. https://doi.org/10.5539/jas.v7n3p111

[21] Novak, J.M., Lima, I., Xing, B., Gaskin, J.W., Steiner, C., Das, K.C., Ahmedna, M., Rehrah, D., Watts, D.W., Busscher, W.J. and Schomberg, H. (2009) Characterization of Designer Biochar Produced at Different Temperatures and Their Effects on a Loamy Sand. Annals of Environmental Science, 3, 195-206.

[22] Brandstaka, T., Helenius, J., Hovi, J., Kivelä, J., Koppelmäki, K., Simojoki, A., Soinne, H. and Tammeorg, P. (2010) Biochar Filter: Use of Biochar in Agriculture as Soil Conditioner. Report for BSAS Commitment, unpublished.

[23] Martinez-Jimenez, J., Garcia-Arostegu, J.L., Hunink, J.E., Contreras, S., Baudron, P., and Candela, L. (2006) The Role of Groundwater in Highly Human-Modified Hydrosystems: A Review of Impacts and Mitigation Options in the Campo de Cartagena-Mar Menor Coastal Plain (SE Spain) (a Review). NRC Research Press, 16 p.

[24] Kwapinski, W., Byrne, C.M.P., Kryachko, E., Wolfram, P., Adley, C., Leahy, J.J., Novotny, E.H. and Hayes, M.H.B. (2010) Biochar from Biomass and Waste. Waste and Biomass Valorization, 1, 177-189. https://doi.org/10.1007/s12649-010-9024-8

[25] Rifai, M.A. (1969) A Revision of the Genus Trichoderma. Mycological Paper, 116, $1-56$.

[26] Glare, T.R. and Inwood, A. (1980) Morphological and Genetic Characterization of Beauveria spp. from New Zealand. Mycological Research, 102, 250-256. https://doi.org/10.1017/S0953756297005005

[27] SAS Institute Inc (2011) SAS OnlineDoc ${ }^{\circledR}$ 9.3. SAS Institute Inc., Cary.

[28] Sobulo, R.A. and Osiname, O.A. (1981) Soils and Fertilizer Use in Western Nigeria. Tech. Bull. No. 11, Institute of Agricultural Research and Training, University of Ife, Nigeria, 8-9.

[29] Onwuka, M.I. and Nwangwu, B.C. (2016) Roles of Biochar Produced from Animal and Plant Wastes on Okra (Abelmoschus esculenta) Growth in Umudike Area of Abia State, Nigeria. Journal of Agriculture and Sustainability, 9, 158-174.

[30] Fischer, D. and Glaser, B. (2012) Synergisms between Compost and Biochar for Sustainable Soil Amelioration. In: Sunil, K. and Bharti, A., Eds., Management of Organic Waste, InTech, Rijeka, 167-198. https://doi.org/10.5772/31200 
[31] Schulz, H. and Glaser, B. (2012) Effects of Biochar Compared to Organic and Inorganic Fertilizers on Soil Quality and Plant Growth in a Greenhouse Experiment. Journal Plant Nutrient Soil Science, 175, 410-422. https://doi.org/10.1002/jpln.201100143

[32] Prost, K., Borchard, N., Siemens, J., Kautz, T., Séquaris, J.M., Möller, A. and Amelung, W. (2013) Biochar Affected by Composting with Farmyard Manure. Journal Environmental Quality, 4, 164-172. https://doi.org/10.2134/jeq2012.0064

[33] Sarah, C., Simon, S., Saran, S., Tan, B.S. and Stephan, H. (2013) The Impact of Biochar Application on Soil Properties and Plant Growth of Pot Grown Lettuce (Lactuca sativa) and Cabbage (Brassica chinensis). Agronomy, 3, 404-418. https://doi.org/10.3390/agronomy3020404

[34] MoyinJesu, E.I. (2003) Incorporation of Agro-Industrial Biomass and Their Effects on Growth and Nutrient Content of Arnaranthus. Journal of Tropical Agricultural Science Malaysia, 26, 49-58.

[35] Lecuona, R.E., Turica, M., Tarocco, F. and Crespo, D.C. (2005) Microbial Control of Musca domestica (Diptera: Muscidae) with Selected Strains of Beauveria bassiana. Journal of Medical Entomology, 42, 332-336. https://doi.org/10.1093/jmedent/42.3.332

[36] Pirali-Kheirabadi, K., Haddadzadeh, H., Razzaghi-Abyaneh, M., Bokaie, S., Zare, R., Ghazavi, M. and Shams-Ghahfarokhi, M. (2007) Biological Control of RhipicephaIus (Boophilus) annulatus by Different Strains of Metarhizium anisopliae, Beauveria bassiana and Lecanicillium psalliotae Fungi. Parasitology Research, 100, 1297-1302. https://doi.org/10.1007/s00436-006-0410-x

[37] Mishra, S. and Malik, A. (2012) Comparative Evaluation of Five Beauveria Isolates for Housefly (Musca domestica L.) Control and Growth Optimization of Selected Strain. Parasitology Research, 111, 1937-1945. https://doi.org/10.1007/s00436-012-3039-y

[38] Benitez, T., Rincon, A.M., Limon, M.C. and Codon, A.C. (2004) Biocontrol Mechanisms of Trichoderma Strains. International Microbiology, 7, 249-260.

[39] Harman, G.E., Howell, C.R., Viterbo, A., Chet, I. and Lorito, M. (2004) Trichoderma spp. Opportunistic Avirulent Plant Symbionts. Nature Reviews Microbiology, 2, 43-56. https://doi.org/10.1038/nrmicro797

[40] Renio, J.L., Guerrero, R.F., Hernandez-Galan, R. and Collado, I.G. (2008) Secondary Metabolites from Species of the Biocontrol Agent Trichoderma. Phytochemistry Reviews, 7, 89-123. https://doi.org/10.1007/s11101-006-9032-2

[41] Glaser, B., Haumaer, L., Guggenberger, G. and Zech, W. (2001) The Terra Preta Phenomenon: A Model for Sustainable Agriculture in the Humid Tropics. Naturwissenschaften, 88, 37-41. https://doi.org/10.1007/s001140000193

[42] Rondon, M.A., Lehmann, J., Ramirez, J. and Hurdalo, M. (2007) Biological Nitrogen Fixation by Common Beans (Phaseous vulgaris L.) Increases with Biochar Additions. Biology and Fertility of Soil, 43, 699-708. https://doi.org/10.1007/s00374-006-0152-z

[43] Ilesanmi, A.O. (2015) Effects of Different Sources and Proportions of Biochar on Soil Carbon Sequestration Rates and Yield of Maize (Zea mays L.). Ph.D. Thesis Submitted to the Institute of Ecology and Environmental Studies, Obafemi Awolowo University, ILE-IFE, $200 \mathrm{p}$.

[44] Scotti, R., Bonanomi, G., Scelza, R., Zoina, A. and Rao, M.A. (2015) Organic Amendments as Sustainable Tool to Recovery Fertility in Intensive Agricultural Systems. Journal of Soil Science and Plant Nutrition, 15, 333-352. 
https://doi.org/10.4067/S0718-95162015005000031

[45] MoyinJesu, E.I. (2012) Comparative Evaluation of Modified Neem Leaf, Neem Leaf and Wood Ash Extracts on Soil Fertility Improvement, Growth and Yield of Maize (Zea mays L.) and Water-Melon (Citrullus lanatus) (Sole and Intercrop). Agricultural Sciences, 3, 90-97. https://doi.org/10.4236/as.2012.31012

[46] Hammond, J.A.R. (2009) The Best Use of Biomass Greenhouse Gas Life Cycle Analysis of Predicted Pyrolysis Systems. M.Sc. Thesis, University of Edinburgh, Edinburgh.

[47] Ofori-Frimpong, K., Afrifa, A.A., Osei-Bonsu, K. and Appiah, M.R. (2003) Cocoa/Coconut Intercropping Trial in Ghana: Effect of the Cropping Systems on Soil Nutrient Dynamics. 14th International Cocoa Research Conference, Accra Ghana, 13-18 October 2003, 13-18. 